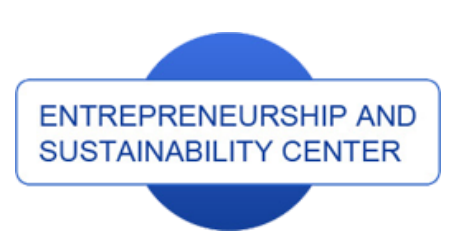

Publisher

http://jssidoi.org/esc/home enterprise

europe

network

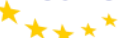

Business Support on Your Doorstep

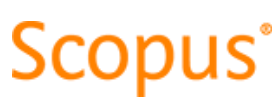

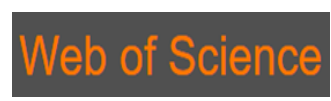

1 Clarivate

Analytics

\title{
SUSTAINABILITY OF ORGANIZATION PERFORMACE VIA MANAGEMENT TECHNIQUES
}

\author{
Vladimír Kubešs , Jan Rančák ${ }^{2}$ \\ ${ }^{1,2}$ University of Chemistry and Technology in Prague, A, Technická 5, 16628 Praha 6 - Dejvice-Praha 6, Czech Republic \\ E-mails: ${ }^{1}$ kubes@intermont-nabytek.cz, ${ }^{2}$ jan.rancak@vscht.cz
}

Received 15 February 2018; accepted 20 May 2018; published 30 June 2018

\begin{abstract}
The article deals with some aspects of relationships with furniture market customers. The research results are presented to identify customer value attributes that are important for customer's choice, satisfaction and value reporting tools. It has been found out that the most important value attributes are high quality of the furniture design, willingness and kindness of the staff, the professional level of the staff and the variety of designs. The least important value attributes are the loyalty programme, the first purchase discount and the architect's advice. Personal information resources are more important for the customer than the impersonal ones. The Internet is primarily used as a source of information about furniture in general and it is used to get an overview before buying in a brick and mortar shop. These findings form a basis of a properly designed effective strategy for maintaining current customers and acquiring new ones.
\end{abstract}

Keywords: sustainability of performance; management; customer relationship management; furniture market

Reference to this paper should be made as follows: Kubeš, V; Rančák, J. 2018. Sustainabilty of organization performance via management techniques, Entrepreneurship and Sustainability Issues 5(4): 1031-1042. http://doi.org/10.9770/jesi.2018.5.4(23)

JEL Classifications: M31

Additional disciplines: sociology; psychology

\section{Introduction}

The current marketing concept is to bring our customers and consumers a bigger value focused mainly on the importance of building relationships with customers and other business stakeholders to be able to stay competitive and remain on the market via management techniques. Payne, Frow (2005) state, that relationship marketing requires more focus on building the relationships in the value network, than in the transactions themselves, more focus on creating value for the customer and moving from acquiring new customers to maintaining the current ones and strengthening their loyalty. The basis for acquiring and maintaining customers is to create and offer 
value that addresses the customers and fullfills their wishes with a focus on marketing techniques. Creating the value for customers is considered the basis of the marketing concept (Woodruf, 1997) and the basis for all marketing activities. Woodall (2003) considers it a precursor of customer's satisfaction and loyalty.

\section{The current state}

\subsection{Sustainability of organization performance}

There are many customer value definitions, of course. According to Zeithaml (1988), for example, the value for the customer is the relative ratio of what they get and what they have to spend on it. Khalifa (2004) defined customer value as the difference between the customer perception of the benefits received and the sacrifices made. Customer benefits include the material and non-material components of the purchased product/service. The components of the sacrifice include cash and non-cash services. Buttle (2009) provides a simple definition that the value of the customer's perception of the result is a comparison of the benefits and the sacrifices they had to make. At the same time he offers a simple calculation of value as a share of benefits and sacrifices. He states more specificaly what must the customer sacrifice to get the product, i. e. not only the product price, but also the mental aspects of the purchase. The purchase might be demanding or stressful if the customer percieves higher risk associated with the operational, physical, financial, social and psychological characteristics of the purchased product (Filip, Šimák, Kováč, 2011). The diversity of the concept of value for the customer has been generalized by Loštáková (2009), who states that the value for the customer is always associated with a particular product or service and is more the customer's perception than an objectively determined fact by the seller or somebody else. Customer perception is a comparison and evaluation of what the customer gets (quality, benefits) and with what they need to do (such as paying a certain price, making efforts associated with additional costs, so called opportunity cost or maintanance cost). It applies to everything the companies do and for which the customer is willing to pay.

The current trend is creating a value for customers based on a complex solution of their needs. Evanschitzky, Wangenheim and Woisetschlager (2011) defines a complex customer need solution as ,an individualized offer for solving customer problems that is interactively designed and when the components bring the customer added value through a combination of products and services in a way, when the value is higher than just a set of components." Creating a value for customers is associcated with all stages of the purchasing process, from the identification of the need, through providing the information for selection of the purchased product, the purchase itself, to the purchase evaluation and behavior.(Filipová, 2016), (Vaysilova,2016).

Kothandarman and Wilson (2001) emphasize, that creating value depends on the company's ability to deliver a higher level of performance in benefits, that are important for the customer, and this ability stems from the company powers in technology and business.

Baines, Fill and Page (2008) state, that the value is relative in relation to the needs, expectations and experiences of the competitive offers within the product cathegory. They add, that the value can also arise from sources different than the product itself and the price, such as branded associations, training programmes for users or legal services. According to Simpson, Sigauw and Baker (2001) it is also the relationship itself between the buyer and the seller, which can create real value, if it is a long-term relationship and if it is difficult for competitors to disrupt it. In addition to excellent products and support services, Loštáková at al. (2017) emphasizes the importance of building customer relationships by taking care of them permanently and creating more brand value for the customers. 
The International Journal

ENTREPRENEURSHIP AND SUSTAINABILITY ISSUES

ISSN 2345-0282 (online) http://jssidoi.org/jesi/

2018 Volume 5 Number 4 (June)

http://doi.org/10.9770/jesi.2018.5.4(23)

At present the value is a well known and widely discussed concept for customers. Particular attention is paid to definic the attribute value for the customer. It is not possible to measure the value the customer percieves. What is possible, however, is to reveal certain value attributes for the customer and, based on them, to create and design the value that a company will offer to customers (Smith, Colgate, 2007).

\subsection{Value attributes}

The primary dimension of value attributes for a customer is their importance, usefulness, beneficial effect for the customer. Loštáková (2009) emphasizes that it is necessary to know the customer's demands, ie. to identify attribute values for the customer, but also to find out how important and beneficial they are for them. Kotler and Keller (2006) recommend the implementation of a more stages process of analyzing the value by identifying the customer's characteristics, and benefits the customer values. The above quoted authors suggest the following step to be a segmentation and finding out how customers value the individual attributes of the value of competing companies. Customer's ideas and preferences can be very different from the perception of the importance of the producer's offer parametres. Smith and Colgate (2007) divided customers' value into four cathegories.

Functional-instrumental value cathegory includes whether a product or service has precise features, functions, quality, aesthetics, etc., the correct function, performance, reliability, service level, servce support, and whether their use is effective. Another important attribute is the impact on the environment and how much it costs. The experience-hedonic value cathegory expresses how a product or service supports customer's emotions, experiences, feelings like joy, confidence, or encouragement of curiosity or surprise. The cathegory of symbolicexpressive attributes expresses the degree of psychological significance of a product or service as a feeling of social prestige or expression of life style. A set of attributes related to "sacrifices" is associated with the cost of the purchase, owning and using the product and efforts to minimize the costs, the price, the product use expenses and to offer comfort, minimalizme psychological stress and the customer's personal input associated with time consuming purchases, to reduce the effort and the energy to buy and use the product or to offer warranties and the possibility of returning the product.

\subsection{The strategy of customer relationships on the market of long-term consumer goods}

Long-term consumer goods are goods that are not frequently purchased. It is intended for longer and repeated use in the household, it's usually stated to last at least three years. While fast-moving goods are purchased when they are consumed, long-term goods have a considerably longer service life and a buying frequency. Customer relationship management strategy in the consumer market has been a focus of interest in recent years. According to Palmer, Lindgreen and Vanhamme (1995) the strategy can be expected to be applied to goods where there is a risk of uncertainity connected with the purchase and the use. Franwick, Porter and Crosby (2001) argue that the application of the strategy can be expected more in the case of commodities, where the purchase involves a complex decision-making process.

According to O'Malley and Tynan (2000), customer relationship building is possible where goods are purchased with high interest, there is a non-elastic demand for the goods and there is a series of interactions between the producer (seller) and the customer. Sorce and Edwards (2004) implemented a research to illustrate how customers percieve "relationships" with the producer. Significant attributes included empathy as an expression of individual attention by the company, personal knowledge of the customers and their needs, a certain length of mutual contacts, and the ability to adapt in terms of service of the willing employees and product delivery, which the authors of the study generalized in the term "unique services for customers". Other attributes of relationship included respondents getting the product they are satisified with according to their requirements and expectations. 
The International Journal

ENTREPRENEURSHIP AND SUSTAINABILITY ISSUES

ISSN 2345-0282 (online) http://jssidoi.org/jesi/

2018 Volume 5 Number 4 (June)

http://doi.org/10.9770/jesi.2018.5.4(23)

They considered an easy, open communication focused on solving possible problems and highlighting news in the goods and services an important attribute, too.

The importance of selected attributes of wooden furniture for customers has been dealt with in several studies. Rammetsteiner, Oberwimmer and Gschwand (2007) presented the results of 13 representative national studies, mostly with with regional focus. Based on the research implemented in five European countreis, the purchasing criteria for buying wooden furniture are similar, although the order of their importance varies from country to country. The attributes of quality, durability, appealing shape and material, and a good price are considered the most important buying criteria, regardless of the type of furniture purchased. The environmental aspects were assessed as less important. Even less significant were the attributes of fashionability, exclusivity or domestic origin. However, the availability of information on the type of wood and its origin has a positive effect on buying behaviour. Further research in European countries has shown that consumers demand good quality especially for the furniture used in the kitchen, bedroom and living room, and they consider the quality of design, comfort, durability and functionality the main components of the offer. The good quality of wooden furniture is usually associated with the kind and the type of wood. The importance of quality increases with the expected product life of the furniture. The ranking is a result of the average rating and according to the authors of the study does not reflect the attitudes and the views of specific customer segments. Regional researches that have been carried out in individual countries include sets of similar purchasing attributes, although with different order of importance.

While in Bulgaria the four most important attributes included price, durability, design and functionality, consumers in Slovakia and Croatia considered the attributes of material and price more important than price. Consumers in Sweden consider the environmental characteristics and environmental impacts of furniture production to be very important attributes. The authors of the study (Rammetsteiner, 2004) comment on the findings as being more generally valid than as reliable and accurate specifications of attitudes and consumer behaviour. It is clear that in the studies carried out so far, attention has not been paid to customer value components that are now centered on customer value-oriented market. Ozzane and Smith (1995) identified the design, type of the wood an price as the main shopping attributes. According to Kotler (2007), companies can use the marketing research methods to find out what features the consumer percieves as the most important and the most ideal within a particular cathegory of products and services, and according to the findings, they can direct the marketing strategy for each specific segment of customers to fullfill their special wishes, needs and interests.

\section{Experimental part}

It is clear that the basic prerequiste for forming and maintaining relationships with customers is the knowledge of what benefits the customers want and prefere. It is therefore about bringing the customers a valuable way of addressing their needs and requirements, accompanied with a set of services and different type sof support. This kind of information should be obtained with regards to the relations and context of the particular field and business, and it can be information about design, packaging, advisory services, range of guarantees, reliability, supplies, etc. To identify the importance of individual supply components for customers and other determinants of their purchasing behaviour, a survey was carried out in May 2017 by Kubeš (2017). The method of electronic questionning was used to address 2,400 customers of the company, who realized a purchase of furniture at the selected company form January 2016 to May 2017. A total of 195 completed questionnaires were obtained back. A set of 15 bidding attributes and 9 supply information sources was compiled through individual interviews with marketing and sales staff, who are in daily contact with the end customers, and using the knowledge that is presented in the theoretical part of this article. The questions identified the importance of each bidding factor for purchasing decisions using a 5 point scale of importance. The Table 1 shows the codes for the individual positions of the scales used. 
Table 1. The scale of the factor importance

\begin{tabular}{|l|l|l|l|l|}
\hline Very important & $\begin{array}{l}\text { Rather important } \\
12\end{array}$ & $\begin{array}{l}\text { Neither important nor } \\
\text { unimportant 13 }\end{array}$ & $\begin{array}{l}\text { Rather unimportant } \\
14\end{array}$ & $\begin{array}{l}\text { Completely } \\
\text { unimportant } \\
15\end{array}$ \\
\hline
\end{tabular}

Source: author

The questionnaire included not only questions about age, sex, the size of the residence and education, but also open questions directed to the topic of purchasing and using purchased furniture. The evaluation of questions focused on other determinants of buying behaviour is not part of this article.

Due to the nature of the research, the individual questions are described using frequencies (relative rates, modus, median, and quantum rates were used). The chi-quadrate and median test were used to identify dependencies between respondents' views and selected descriptive characteristics. If chi-quadratic differencies were identified by differencies in opinions, or actions of the individual cathegories of respondents, these differencies are statistically significant at the chosen level 0.05 . The structure of the assessment of the individual components of the offer is different from the customer's point of view, see Tab. $2 a, 2 b$.

Table 2a. The Importance of Each of the Components of the Offer for Satisfaction with the Purchase of Furniture

\begin{tabular}{|c|c|c|c|c|c|}
\hline The attributes of the offer & \multicolumn{5}{|c|}{ Relative frequencies of levels of importance for customers (\%) } \\
\hline Importance & $\begin{array}{l}\text { Very important } \\
\text { (11) }\end{array}$ & $\begin{array}{c}\text { Rather } \\
\text { important (12) }\end{array}$ & $\begin{array}{c}\text { Neither } \\
\text { nor } \\
(13)\end{array}$ & $\begin{array}{l}\text { Rather unimportant } \\
\text { (14) }\end{array}$ & $\begin{array}{c}\text { Completely } \\
\text { unimportant (15) }\end{array}$ \\
\hline wide range of furniture & 17,4 & 36,9 & 16,4 & 22,1 & 7,2 \\
\hline different designs & 25,1 & 50,3 & 3,1 & 10,3 & 11,3 \\
\hline high quality & 45,1 & 34,9 & 1,5 & 7,2 & 11,3 \\
\hline architect's advice & 8,7 & 25,1 & 35,9 & 22,1 & 8,2 \\
\hline professional level of staff & 37,9 & 39,5 & 4,1 & 6,7 & 11,8 \\
\hline willingnes, kindness of staff & 54,9 & 25,1 & 1,5 & 3,1 & 15,4 \\
\hline quality printed catalogue & 12,3 & 32,8 & 27,2 & 20,0 & 7,7 \\
\hline detailed information online & 22,1 & 43,1 & 15,9 & 12,8 & 6,2 \\
\hline recommendation of furniture care & 13,3 & 40,0 & 23,6 & 16,9 & 6,2 \\
\hline individual tailoring & 30,3 & 43,1 & 7,7 & 10,3 & 8,7 \\
\hline home installation & 24,1 & 36,9 & 14,9 & 12,3 & 11,8 \\
\hline availability of the store & 19,0 & 41,5 & 21,5 & 9,2 & 8,7 \\
\hline loyalty programme & 3,6 & 19,0 & 35,9 & 22,1 & 19,5 \\
\hline first purchase discount & 5,1 & 25,6 & 31,3 & 22,6 & 15,4 \\
\hline design using computer visualisation & 12,8 & 31,3 & 28,2 & 16,9 & 10,8 \\
\hline
\end{tabular}

Table 2b. The Importance of Each of the Components of the Offer for Satisfaction with the Purchase of Furniture 
The International Journal

ENTREPRENEURSHIP AND SUSTAINABILITY ISSUES

ISSN 2345-0282 (online) http://jssidoi.org/jesi/

2018 Volume 5 Number 4 (June)

http://doi.org/10.9770/jesi.2018.5.4(23)

\begin{tabular}{|c|c|c|c|c|}
\hline \multirow[b]{2}{*}{ The attributes of the offer /importance } & \multirow[b]{2}{*}{ Modus } & \multicolumn{3}{|c|}{ Kvartils } \\
\hline & & 25 & 50 & 75 \\
\hline \multicolumn{5}{|l|}{ Importance } \\
\hline wide range of furniture & 12 & 12 & 12 & 14 \\
\hline different designs & 12 & 11 & 12 & 12 \\
\hline high quality & 11 & 11 & 12 & 12 \\
\hline architect's advice & 13 & 12 & 13 & 14 \\
\hline professional level of staff & 12 & 11 & 12 & 12 \\
\hline willingnes, kindness of staff & 11 & 11 & 11 & 12 \\
\hline quality printed catalogue & 12 & 12 & 13 & 14 \\
\hline detailed information online & 12 & 12 & 12 & 13 \\
\hline recommendation of furniture care & 12 & 12 & 12 & 13 \\
\hline individual tailoring & 12 & 11 & 12 & 13 \\
\hline home installation & 12 & 12 & 12 & 13 \\
\hline availability of the store & 12 & 12 & 12 & 13 \\
\hline loyalty programme & 13 & 13 & 13 & 14 \\
\hline first purchase discount & 13 & 12 & 13 & 14 \\
\hline design using computer visualization & 12 & 12 & 13 & 14 \\
\hline
\end{tabular}

It is clear from the results presented in the above tables that the attributes of the high quality of the furniture design and the willingness and kindness of the staff were the most often regarded as the very important for the customers' choice and satisfaction. The willingness and kindness of the staff were regarded as very important even more often than the professional level of the staff. Individual furniture tailoring, which was mentioned as very important by 30 percent of the respondents, is related to the trend of customer service individualization and offering exactly what the customers want and expect. This fact is also supported by the frequency of importance of the attribute different designs, where the customers are offered a variety of wood types, surface treatments and even upholstered furniture finishes. It is ineteresting that offering a wide range of furniture is not very important for customers. On the contrary, the least frequent components of the offer were the loyalty programme, the first purchase discount or the architect's advice.

After summing up the frequencies of the very important and important responses, the following order of the offer components importance was found out: high quality of furniture design, willingness and kindness of staff, professional level of staff, different designs, individual tailoring, detailed information online, more than 60 percent of customers suggested home installation very important. On the other hand, the loyalty programme and the first purchase discount were shown as the least important for customers' choice and satisfaction. The design using computer visualisation ( $44 \%$ in total) proved to be more important than architect's advice (rather important or very important for $33 \%$ of customers). The most neutral responses (neither important nor unimportant) is connected to architect's advice (35\%), loyalty programme $(35 \%)$, first purchase discount $(31 \%)$ and quality printed catalogue $(27 \%)$. 
The International Journal

ENTREPRENEURSHIP AND SUSTAINABILITY ISSUES

ISSN 2345-0282 (online) http://jssidoi.org/jesi/

2018 Volume 5 Number 4 (June)

http://doi.org/10.9770/jesi.2018.5.4(23)

Table 3. Relationship between the Importance of Characteristics and Selected Descriptive Characteristics of Respondents (Consensus of the Distribution)

\begin{tabular}{|c|c|c|c|c|c|}
\hline $\begin{array}{l}\text { Question about } \\
\text { importance }\end{array}$ & $\begin{array}{l}\text { Characteristi } \\
\text { c }\end{array}$ & $\begin{array}{l}\text { Test } \\
\text { type }\end{array}$ & $\begin{array}{l}\text { Asymp. } \\
\text { Sig. }\end{array}$ & $\begin{array}{l}\text { Monte } \\
\text { Carlo Sig. }\end{array}$ & Descriptiton \\
\hline High quality & Age & $\begin{array}{l}\text { Chi- } \\
\text { square }\end{array}$ & 0,018 & 0,024 & The higher the age the more important the quality \\
\hline $\begin{array}{l}\text { Architect's } \\
\text { advice }\end{array}$ & Age & $\begin{array}{l}\text { Chi- } \\
\text { square }\end{array}$ & 0,000 & 0,000 & The higher the age the more important architect's advice \\
\hline $\begin{array}{l}\text { Professional } \\
\text { level of staff }\end{array}$ & Age & $\begin{array}{l}\text { Chi- } \\
\text { square }\end{array}$ & 0,003 & 0,004 & $\begin{array}{l}\text { Proffesional level of staff is the most important for the age } \\
\text { group } 55 \text { and higher }\end{array}$ \\
\hline \multirow[t]{2}{*}{$\begin{array}{l}\text { Quality printed } \\
\text { catalogue }\end{array}$} & Education & $\begin{array}{l}\text { Chi- } \\
\text { square }\end{array}$ & 0,001 & 0,001 & $\begin{array}{l}\text { The higher the age the more important quality printed } \\
\text { catalogue. It is the least important for the age group } 35 \text { and less }\end{array}$ \\
\hline & Education & $\begin{array}{l}\text { Chi- } \\
\text { square }\end{array}$ & 0,036 & 0,035 & $\begin{array}{l}\text { For the respondents with secondary education quality printed } \\
\text { catalogue is very important }\end{array}$ \\
\hline $\begin{array}{l}\text { Loyalty } \\
\text { programme }\end{array}$ & Education & $\begin{array}{l}\text { Chi- } \\
\text { square }\end{array}$ & 0,042 & 0,041 & $\begin{array}{l}\text { Loyalty programme is more important for respondents with } \\
\text { secondary education }\end{array}$ \\
\hline $\begin{array}{l}\text { Design using } \\
\text { computer } \\
\text { visualisation }\end{array}$ & $\begin{array}{l}\text { Size of the } \\
\text { residence }\end{array}$ & $\begin{array}{l}\text { Chi- } \\
\text { square }\end{array}$ & 0,031 & 0,030 & $\begin{array}{l}\text { It is the least important for inhabitants of villages up to } 999 \\
\text { inhabitants, the most important for inhabitants of towns } \\
\text { populated } 1000 \text { to } 100000 \text { inhabitants }\end{array}$ \\
\hline
\end{tabular}

Source: author

The opinions of the importance of the bidding attributes for the selection and satisfaction differed only for five out of the total 15 attributes, see Table 3. Based on the used characteristics, it can be said that the main source is the respondent's age, the education, and somewhat surprisingly size of the residence. To communicate with customers, it is important to know which source they consider the more or less important.

Customers can search for information from different sources. Deeper search can result not only in gaining a higher level of benefits and risk reduction, but also more confidence in the purchase. External sources include advertising, the Internet, social media, sales brochures and interpersonal resources such as family friends. Literature sources quoted in the theoretical part suggest that the importance of personal and non-personal sources will vary. A summary of the views of the sources of information before purchasing furniture is given in the Table 4. 
Table 4. Sources of information before and during the purchase of furniture

\begin{tabular}{|l|c|c|c|c|}
\hline \multicolumn{1}{|c|}{ Information before purchase } & \multicolumn{3}{c|}{ Quartiles } \\
\cline { 3 - 5 } & \multirow{2}{*}{ Modus } & 25 & 50 & 75 \\
\hline -TV commercials & 5 & 4 & 4 & 5 \\
\hline -TV programmes & 5 & 3 & 3 & 5 \\
\hline -web pages & 2 & 2 & 2 & 3 \\
\hline -adds & 4 & 3 & 4 & 5 \\
\hline -social network & 5 & 3 & 4 & 5 \\
\hline -catalogues, brochures & 2 & 2 & 2 & 3 \\
\hline -friends and their experience with furniture at home & 2 & 2 & 2 & 3 \\
\hline -recommendation of family and friends & 3 & 2 & 3 & 4 \\
\hline -sellers'advice & 2 & 2 & 2 & 3 \\
\hline
\end{tabular}

Source: author

Generally, personal sources can be considered the most used information sources before purchasing furniture, especially sellers' advice right in the shops, friends and their experience with furniture at home. Non-personal sources include producers' web pages, catalogues and brochures. On the contrary, the least used are TV commercials, magazine adds and social networks. Looking at the structure of responses, it has been found that using TV as a source of information differs depending on the gender and education of the respondents, see Tab. 5.

Table 5. The Relationship between the Use of Information Sources and Gender and Education

\begin{tabular}{|l|l|l|l|l|}
\hline Question & $\begin{array}{l}\text { Describing } \\
\text { Characteristics }\end{array}$ & Test Type & Asymp. Sig. & \multicolumn{1}{|c|}{ Descrption of differences } \\
\hline $\begin{array}{l}\text { TV programmes } \\
\text { as a source of } \\
\text { information }\end{array}$ & Gender & $\begin{array}{l}\text { Chi- } \\
\text { square }\end{array}$ & 0,001 & $\begin{array}{l}\text { Women use TV programmes about living as a } \\
\text { source of information more often than men }\end{array}$ \\
\cline { 2 - 5 } & Education & $\begin{array}{l}\text { Chi- } \\
\text { square }\end{array}$ & 0,003 & $\begin{array}{l}\text { Respondents with secondary education watch TV } \\
\text { programmes about living more than respondents } \\
\text { with university education }\end{array}$ \\
\hline
\end{tabular}

Source: author

A significant trend today is the use of modern technologies while communicating with the customers. In order to find out the respondents' views on the use of the Internet for collecting information, realization of the purchase and finding out the content requirements for furniture on the Internet, four questions were formed. Based on their evaluation in Tab. 6 it appears that the Internet is primarily used as a source of infromation about furniture in general and to get a general overview before the purchase in a brick and mortar shop.

Table 6. Opinions about Finding Information and Purchasing Furniture on the Internet

\begin{tabular}{|c|c|c|c|c|}
\hline & \multirow[t]{2}{*}{ Median } & \multicolumn{3}{|c|}{ Quartiles } \\
\hline & & 25 & 50 & 75 \\
\hline Internet as a source of information about furniture & 2,00 & 1,00 & 2,00 & 2,00 \\
\hline Using the Internet before purchase in the brick and mortar shop & 2,00 & 1,00 & 2,00 & 2,00 \\
\hline Demand of easier and wider offer on the Internet & 3,00 & 2,00 & 3,00 & 3,00 \\
\hline Presenting interiors on the Internet & 2,00 & 2,00 & 2,00 & 3,00 \\
\hline Buying furniture on the Internet (YES, NO) & 2,00 & 1,00 & 2,00 & 2,00 \\
\hline
\end{tabular}

Source: author 
The respondents would also welcome presentations of interiors on the producer's websites, the current view on an easier and wider realization of purchase through an e-shop is generally neutral. This may be due to respondents' lack of experience in this field. To verify this assumption, the relationship between opinions of respondents who have already realized the purchase on the Internet and those who have not done so yet has been examined. Almost $60 \%$ of those who have already experienced buying furniture on the Internet agree with the demand of easier and wider offer and an easier realization of the purchase compared to 39\% of the group of respondents who do not have such an experience yet. The results are shown in Tab. 7.

Table 7. The Relationship between Demand of Wider Offer on the Internet and Easier Purchase on the Internet and Online Shopping Experience

\begin{tabular}{|l|l|l|l|l|}
\hline Question & $\begin{array}{l}\text { Describing } \\
\text { Characteristics }\end{array}$ & Test Type & Assymp. Sig. & Description \\
\hline $\begin{array}{l}\text { Demand of Wider Offer } \\
\text { and Easier Purchase on } \\
\text { the Internet }\end{array}$ & $\begin{array}{l}\text { The Experience } \\
\text { of Shopping } \\
\text { Online (YES/NO) }\end{array}$ & Chi- square & $\begin{array}{l}0,006 \\
\text { df } 4\end{array}$ & $\begin{array}{l}\text { The experienced online shoppers demand wide offer } \\
\text { and easier purchase on the Internet }\end{array}$ \\
\hline
\end{tabular}

Due to the growth in the proportion of online purchases, we can expect an increase in interest in purchasing furniture through e-shops in the near future. Furniture vendors must therefore pay much more attention to ways of presenting furniture on the Internet, visualizing home furniture solutions, developing distribution systems, and, last but not least, linking the information system to social networks as Facebook. According to the study (Wang, 2017) the usage of the social media into customer relationship management system can improve the company performance. For our business, it means not only to expand the offer for internet sales, enhance the ability to deliver goods including application services, to offer other products in the moment of the delivery. The interconnection of management information system with social media can build competitive advantage

\section{The Limitation of the Research}

The acquired knowledge is valid within a set of data obtained from customers of the selected company. Furthemore, the research was based on the size of the group of respondents who agreed to cooperate. From the magnitude of the achieved statistical characteristics it can be concluded that larger files could be uncovered and further connections between them could be found.

\section{Conclusion}

The starting point was the study of the current state of the customer relationship management strategy concept, which emphasizes not only acquiring new customers, but mainly maintaining the current ones. In the industrial and commodity markets, this trend is provable. The question is wheter this trend fully applies also with the longterm consumption goods, in particular in the wooden furniture market, where the average life-expectancy is about 15 years and with upholstered furniture it is 11 years.

Due to this it is not possible to fully accept the current goal of a customer-oriented strategy, to keep the current customers. For companies operating in a limited market, such as in the Czech Republic and Slovakia, it is necessary to combine the strategy of maintaining with the strategy of acquiring new customers. Keeping the customer for more than 10 years and 5 years for upholstered furniture customers requires tools different from short-term consumers' goods. One way to achieve this is combining long-term consumer products with short-term 
The International Journal

ENTREPRENEURSHIP AND SUSTAINABILITY ISSUES

ISSN 2345-0282 (online) http://jssidoi.org/jesi/

2018 Volume 5 Number 4 (June)

http://doi.org/10.9770/jesi.2018.5.4(23)

consumer products, specifically housing accessories with short purchasing cycles. Emphasis should be placed on those components of the importance value, which has been identified through this research. Permanent contact with a customer is also important for acquiring new customers in this area. Given that the customer relationship management strategy on the long-term commodity market has not yet been the subject of more attention, an ongoing research can enhance knowledge in this area.

\section{References}

Baines, P; Fill Ch.; Page, K. 2008. Marketing. Oxford: Published by University Press.

Buttle, F. 2009. Customer Relationship Management: Concepts and Tools. Oxford: Published by Butterworth-Heinemann Cambra-Fiero, J., Centeno, E., Ollavria, A. (2017). Succes Factors in CRM Strategy: Technology Is Not All, Journal of Strategic Marketing 25 (4): 316-333. https://doi.org/10.1080/0965254X.2016.1148760

Ewanschitzky, H; Wangenheim, F.V.; Woisetschlager. D.M. 2011. Servise \& Solution Innovation: Overview and Research Agenda, Industrial Marketing Management (5): 657-660. https://www.sciencedirect.com/journal/industrial-marketing-management/vol/40/issue/5

Filip, S.; Šimák, L.; Kováč, M. 2011. Risk Management.Bratislava.Sprint dva.s.199. ISBN 978-80-89393-49-7.

Filipová, L. 2016. Customer research of non-bank entities, MEST journal 4(2): 94-102. https://doi.org/10.12709

Frankwick G.L.; Porter S.S.; Crosby A.L. 2001. Dynamics of Relationship Selling: A Longitudinal Examination of Changes in Salespersoncustomer Relationship Status, Journal of Personal Selling \& Sales Management 21(2): 135-146. https://www.tandfonline.com/doi/abs/10.1080/08853134.2001.10754264

Giedraitis, A.; Stašys, R.; Skirpstaitè, R. 2017. Management Team Development Opportunities: A Case of Lithuanian Furniture Company, Entrepreneurship and Sustainability Issues 5(2): 212-222. https://doi.org/10.9770/jesi.2017.5.2(4)

Khalifa, A. 2004. Customer Value: A Review of Recent Literature and an Integrative Configuration, Management Decision 32(5): 645-666. https://www.emeraldinsight.com/doi/full/10.1108/00251740410538497

Kothandaraman, P; Wilson, D. 2001. The future of Competition: Value Creating Networks, Industrial Marketing Management 30(4): 37989. https://www.sciencedirect.com/science/article/abs/pii/S0019850100001528

Kotler, P. 2007. Marketing Management, Př́bram. Publised by Grada.

Kotler, P.; Keller, K.L. 2006 Marketing Management. Twelfth ed. Upper Saddle River, NJ: Pearson Prentice Hall. ISBN 978-0131457577.

Kubeš, V. 2017. Strategy of Customer Relationship Management. Dissertation. University of Chemistry and Technology in Prague

Lostakova, H., Jelinkova, M., Vlckova, V.2017 Beneficial effect of Tools for Cooperation and Integration between Chemical Companies and their Customers for Mutual Relationship Strengthening, Chemické listy 111: 404-409. http://www.chemickelisty.cz/ojs3/index.php/chemicke-listy/article/view/76/76

Lošt'áková, H. 2009. Differentiated Customer Relationship Management: (Modern Business Growth Performance Strategy) Praha: Publised by Grada.

Lošt’áková, H. et al 2017. Tools for Straightening Customer Relationships in B2B market. Praha: Publised by Grada Publishing. 
The International Journal

ENTREPRENEURSHIP AND SUSTAINABILITY ISSUES

ISSN 2345-0282 (online) http://jssidoi.org/jesi/

2018 Volume 5 Number 4 (June)

http://doi.org/10.9770/jesi.2018.5.4(23)

O’Malley, L.; Tynan, C. 2000. Relationship Marketing in Consumer Markets. European Journal of Marketing 34 (7): $797-815$. https://link.springer.com/article/10.1057/palgrave.im.4340094

Ozzane L.; Smith P. 1996. Consumer Segments for Environmetally Marketed Woden Household Furniture, Wood and Fiber Science 28 (4): 461-477. https://pennstate.pure.elsevier.com/en/publications/consumer-segments-for-environmentally-marketed-wooden-household-f

Palmer, R.; Lindgreen, A.; and Vanhamme, J. 2005. Relationship marketing: schools of thought and future research directions, Marketing Intelligence \& Planning 23(3): 313-330. https://www.emeraldinsight.com/doi/abs/10.1108/02634500510597337.

Payne A.; Frow, P. 2005. A Strategic Framework for Customer Relationship Management. Journal of Marketing 69(4): 167-176. http://journals.ama.org/doi/10.1509/jmkg.2005.69.4.167? code=amma-site

Rammetsteine, E.; Oberwimmer, R.; Gschwand, T. I. 2007. EUROPEANS AND WOOD. What Do Europeans Think About Wood and its Uses? A Review of Consumer and Business Surveys in Europe. Ministerial Conference on the Protection of Forests in Europe, 2007. ISBN 978-83-926647-0-3.

Simpson P.M.; Sigauw J.A.; Baker, T. 2001. A model of value creation: supplier behaviours a their impact on reseller-perceived value, Marketing Science Review 12. http://irep.ntu.ac.uk/id/eprint/6707/

Smith,J.B.; Colgate, M. 2014. Customer Value Creation: A Practical Framework, Journal of Marketing Theory \&Practice.15 (1): 7-23

Sorce P.; Edwards, K. 2004. Defining Business to Customer Relationships: The Consumer's Perspective. Journal of Database Marketing \& Customer Strategy Management 11(3): 255-267. https://link.springer.com/article/10.1057/palgrave.dbm.3240225

Vaysilova E. 2016. Optimization of the financial result by method "price elasticity of sales", International scientific conference "MENAGEMENT 2016", Belgrade, Serbia, 5-6 May, 2016, p. 284, ISBN 978-86-6375-053-1

Wang, Z., Kim, HG. 2017. Can Social Media Marketing Improve Customer Relationship Capabilities and Firm Performance? Dynamic Capability, Perspective.Journal of Interactive Marketing 39: 15-26. https://doi.org/10.1016/j.intmar.2017.02.004

Woodall, T. 2003. Conceptualization Value for the Customer: An Attributional, Structural and Dispositional Analysis. Academy of Industrial Marketing Management 30(2): 119-34 https://www.tandfonline.com/doi/abs/10.2753/MTP1069-6679150101

Woodruf, R.B. 1997. Customer Value: The Next Source for Competitive Advantage. Journal of the Academy of Marketing Science, 25, 139-153. http://dx.doi.org/10.1007/BF02894350

Zeithaml, V. A. 1988. Consumer Perceptions of Price, Quality, and Value: A Means-End Model and Synthesis of Evidence. Journal of Marketing 52 (3): 2-22. https://www.jstor.org/stable/1251446?seq=1\#page_scan_tab_contents 
Vladimír KUBEŠ is a CEO of INTERLIGNUM a.s. and INTERMONT s.r.o which are companies producing furniture and selling their products in the Czech Republic, Slovakia and Poland. In the research he is interested in the strategy of customer relationship management in the field of furniture and long term consumption goods. He graduated the Technical University in Zvolen, Slovakia in the field of Economy and Management of Wood Industry and got an Engineer Degree, he got a Ph.D. in the University of Chemistry and Technology in Prague, Faculty of Chemical Engineering, Department of Economics and Management.

ORCID ID: orcid.org/ 0000-0003-4544-7140

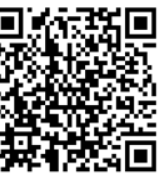

Jan RANČÁK is an associate professor at the University of Chemistry and Technology in Prague (UCT Prague). He graduated in the field of Economy and Management (1975). In 1980 he got a Ph.D. in UCT Prague, Faculty of Chemical Engineering. He was the head of Department of Economics and Management (1989 - 1991) and the Vice Dean of this faculty for the period 1987-90. After that he spent more than 25 years in industry as a CEO or CFO of several companies. He teaches Strategic, Project, Financial and Risk Management.

ORCID ID: h:/orcid.org /0000-0002-5968-2814

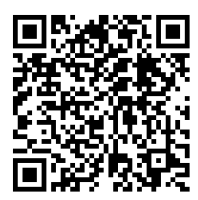

Register for an ORCID ID:

https://orcid.org/register

Copyright (C) 2018 by author(s) and VsI Entrepreneurship and Sustainability Center

This work is licensed under the Creative Commons Attribution International License (CC BY).

http://creativecommons.org/licenses/by/4.0/

(c) (†) Open Access 